\title{
THE IMPACT OF SOCIAL, ECONOMIC AND ENVIRONMENT IN LOCAL COMMUNITY PARTICIPATION OF ARCHEOLOGICAL TOURISM VILLAGE BEDULU GIANYAR, BALI
}

\author{
I Ketut Putra Suarthana, Ni Luh Putu Agustini K, Widi Hardini \\ Triatma Mulya Institute of Economy, Udayana University
}

\begin{abstract}
This study aims to measure the changes in the economic, socio-culture and community environment as the result of community participation at Bedulu tourism village activities. The activities of Bedulu tourist village involved the community in a various sector such as, economic, socio-culture and environment preservations. Quantitative descriptive method with quantitative regression analysis techniques applied in this research. The independent variable of this research is the local community participation $(X)$, whereas the dependent variable consists with three economic impact (Y1), socio-culture (Y2), and environment (Y3). Purposive sampling technique conducted in order to explore the response of 50 respondents with tourism implementation impact in Bedulu tourism village. The sample consists of all local community participations and management in which involved with the tourism village. Findings to this research are the positive impact of the local community participation and significant effect on the change of economic, socio-culture and environmental preservation in Bedulu Tourism Village. The implication of this research is the incremental of local community participations in creative industries based on local community.
\end{abstract}

Keywords: participation, impact, economy, socio-cultre, environment

\section{Introduction}

Bali tourism growing rapidly and focus on some of the favorite destinations in Badung and Denpasar region. The negative symptoms arise as a results of the tourism activity concentration in south of Bali (Sanur, Kuta and Nusadua). The consequences of the uneven tourism development in bali is the rising of long commutes in congested areas of the favorite tourist destinations. At the end of 2013, government constructed the underpass at Dewa Ruci and Denpasar-Ngurah Rai -Nusadua highway in order to reduce the traffic jam and accelerate the way to Bali airport.

The new government policy through the Ministry of Tourism and Creative Economy propelling tourism based on culture able to stimulate people to find the alternative tourism. Bali designated as a tourism destination based on culture and environment through the government. It brings to increase the number of tourists 
visiting Bali, until 2014 reached 4,5 billion (BPS, 2015). There are a various tourism activities based on culture and environment in Bali. Tourism facilities more complete and diverse to support the implementation of Bali communitybased tourism. The stakeholders especially travel agents in Bali mutually increase the tourism services, adapting the needs of tourist. Explore the rice field tour, ATP tour, safari tour, jogging track, Ayung river rafting, mount Batur bike track and offers various tourism activities with the competitive price. It's happened to solve the saturation on beach tourism, resort and shopping tourism. This model makes the stakeholders more creative in creating the cha;;enging tourism models, which is ecotourism and spiritual tourism.

Nature-based cultural tourism involves not only the travelers, but researchers, official government, and the association participation. Shifting the trend of dominance market from European and Australian travelers to China, Japan, Malaysia and Korea (BPS Bali, 2013) makes the Asian market as the main target market for the Bali tourism promotional program. Tourism concept and application bring the multiplier effect to the local community who's involved direct or indirectly. In line with the concept of pro-community (Putra and Pitana, 2010) slightly different with pro-poor tourism concept, pro-poor tourism defines as the alternative strategy for tourism development that bring the benefits to the poor people. In order to distribute the equitable economic benefits and tourism, the Ministry of Tourism and Creativ Economy creates a new alternative strategy by developing community-based tourism that empowers local communities through tourism village. Community-based tourism or commonly known as community-based tourism (CBT) can be used as alternative strategies to breakdown the concept of leisure and shopping which concentrated in southern Bali. This tourism implementation concept model able to support the economic, social, cultural and natural preservation of the local environment. So, how does the implementation of local community participation impact the economic, soci0culture, and environmental sustainability to the Bedulu tourism village?

The very first tourism village implementation in Indonesia located at Tanjung Village, Yogyakarta. The community based tourism village model able to contribute a better economy for the local communities. Winarno (2004) conclude that the emergence of tourist village is due to changes in tourism trends around the world in 1990, better known as the bact to nature, many tourist visit and stay at the village, until finally became known as the tourism village. Jeffry Kairupan as the Director of Indonesian Bank in Bali region 2010 give a support for the tourism village in Bali through corporate social responsibility (CSR) in order to developed Bali tourism based on community (Sulityowati, 2011 cited in kompas.com, 2011). Furthermore, Bank Indonesia in cooperation with Bali Hotel Association choose seven village that are scattered throughout six region in bali, such as: Pinge Village (Tabanan), Bedulu Village (Gianyar), Penglipuran Village (Bangli), Blimbingsari Village (Jembrana), Buda Rivet and Jasri Village (Karangasem) and Pancasari Village (Buleleng). 


\section{Literature Review}

At the conference of the implementations Destination Management Organizations (DMO) Labuanbajo, Ardika (2011) stated that Indonesian tourism norms is divided into three aspects, community based tourism, culture and sustainable development. Tourism village is one of the tangible manifestations implementations in community based tourism concept. Ardika (2011) defines the tourism village as a journey in order to enjoy the atmosphere of rural life, gain the mutual respect and culture, values, traditions and natural environment, results in a two-way learning process between tourist and community, and improve the welfare of rural communities.

\section{Tourism Village Concept as a Pro-Community Tourism Development}

Wacik (2010, cite in Putra and Pitana, 2010) stated that, tourism has a major role for nation-building efforts, which led to improve the community welfare. It seen clearly that tourism has a various characteristic and potential strategic advantages for the implementation of development strategies through 'triple tracks plus one', which is pro-growth, pro-jobs and pro-poor, and proenvironmental concern.

Refer to the Cultural Tourism Ministry Decree No. PM.26/UM.001/MKP/2010 year 2010 defines the tourism village as an integration form between accommodation attraction and the support facilities presented in a structures community life along with the ordinance and prevailing traditions (Putra and Pitana, 2010). Tourism village has a clear goals and objectives for tourism development, it is beneficial to the community because its managed by their own people, for their people, therefore peoples in community must be active, creative and pro-active. Putra and Pitana (2010) stated that the funding of national community empowerment program (PNPM) allocated for the construction and development of tourism village within Indonesia.

\section{Local Community Participation at the Community Based Tourism (CBT)}

In the community based tourism theory, tourism village describe as the implementation of eco tourism requires the participation of local communities. Their participation needed at the form of process so that they can improve their own quality of life and contribute in destination development. Kathiseran (2006) stated, the local community participations absolutely necessary for the conservation and management or the management of natural environment, including mangroves and forests. The join management model or co-management can be a partner agreement in which the government, local communities, public users, external agencies and stakeholders have a common interest in decision making and responsibilities (Pomeroy and Katon, 2000). Rouse (2006) describes the approach of people participation program (PPP) have a similar but more emphasis on the alleviation of rural poverty, women empowerment, community welfare in a small groups and involving the government institutions. Community participation in the local communities development is determined by the 
individual's involvement initiation, planning, decide, implement and manage the activities of the group, as a social process on environment (Samah and Ared, 2009).

Compare with the community participation concept of Indonesian tourism village initiated by Ardika (2011), explained that the people in tourism village should become the actor direct or indirectly, the landlord at the location and not transferable, uphold the partnership principle, local community empowerment with maximum utilization for the community and the preservation of cultural traditions and the environment. There are a various opinion explained that if local communities participating in tourism village development, then the entire community based activities will be realized well.

Refer to the study of community empowerment case in Kiltimagh by Lynch (2012), it stated that the successful and sustainable development is better achieved where its starts from a local physical, social and culture resource base and involved inclusive participant in planning and implementing development. The statement emphasized that the success and the sustainability tourism development will be better to achieved with the base of local physic conditions, socio-culture and entire community involvement in the planning, development and implementation process.

McGettigan and Burns (2004) reveal that the community empowerment through volunteer input as the key criteria at all levels of community development cycle. The voluntary work model pattern builds the communities by empowering them to develop the sense of pride as the resident with culture, heritage, nature and the wealth. A nationalism sense and positive pride will attempt to reduce immigration, enhance creativity and entrepreneurial spirit for the sustainable development of their village. The involvement of volunteer service or initiator in the community development activities tends to give better meaning and memorable.

\section{Government Policy in Community-Based Tourism Development and the Impact on Economic, Social and Environmental}

With the development of science and technology, it facilitates human activities for travelling. Refer to tourism act No. 10 of 2009, it stated that tourism plays an important role in increasing the economic growth, improve the community welfare, reduce the unemployment and poverty alleviation, and raising the Indonesian tourism image.

This act also mandates tourism as a mainstay and potential sector in which capable to gain the foreign exchange, boost the economic growth and regional income, community empowerment economic and increase the job opportunities. Indonesian government through ministry of tourism and creative economy outlines the basic criteria of tourism village development encompasses the proximity to the famous tourist attraction, physical access and market access, has the potential partnership, local community enthusiasm, and the availability of minimal public facilities (Ardika, 2011). 
Related to the development of society, government must play an active role in building local people capacities through participation. The local people capacity building aspired by the government, it should begin with the involvement of local community as well as the actor who can enjoy the implementation program development. Local community participation in governance is the foundation in building social capital, strengthen democracy and facilitate the community sustainability (Cuthill and Fien, 2005).

Islam and Carlsen (2010) stated that, local micro enterprise by the local community is a potential element in building community-based tourism. In this case, government and private organizations (NGO's) contribute for the provision of loans and funding so that the local community can take this as their opportunity. The existences of government, NGO's, and private stakeholders needed by the local communities in tourism village program. In Indonesia, throughout PNPM Mandiri program by the government aims to assist the development of tourism village. In 2012, the Indonesian government developed 972 tourism village through PNPM Mandiri program.

In the community-based tourism, cultural tourism development considered as the best way to attract tourist to destination that have an impact on improving the quality of life as a whole (Cecil et al., 2010). The beaches, hotels and resorts benefits at certain point on the cultural destination (Addo, 2011). Another interesting thing in the development of community-based tourism is popularizing the local food. Handerson (2007) stated that the diversity of food based on location, culture and tradition, in primary and secondary provide good prospects as well as a challenge for the development in tourism industry.

Bedulu archaeological value diversity gives a positive values and efforts in preservation of heritage site. The research finding of Leane and Stephens (2010), describes that marketing and communications required an efforts to balanced between cultural-based tourism and heritage site based touris, given the different target markets. Based on several references that examine the impact of tourist village above, it conclude that the activities of community-based tourism complex impact on people's lives.

\section{Methodology}

Research on Tourism Village Bedulu Archaeological implemented quantitative analysis with simple regression. The measured variable is the community participation $(\mathrm{X})$ in the tourist village activity and its impact on sociocultural (Y1), economic (Y2) and the environment (Y3). With a 1-5 Likert scale, structured questionnaire were distributed to respondents who are competent and

represent criteria. Probability sampling conducted on 52 respondents consist of local communities that are divided into several groups based on their role (participation) in the activities of a tourist village. Criteria respondents; a minimum age of 18 years, and was directly involved in the activities of Bedulu Archaeological Tourism Village. The collected data is processed by using simple regression analysis with SPSS 18, in order to measure of public participation 
partially on the impact of social, cultural, economic and environmental Bedulu Archaeological Tourism Village.

\section{Overview of Archaeological Tourism Village Bedulu}

Astawa (2013) suggests potential for archaeological and cultural Bedulu village is an ancient village which has a very interesting cultural potential. The main potential of this village is a cultural heritage (archeology) sacred and stored in a mock Native village. Another potential Bedulu Village is a painting of the famous figures past are on display in the House Painting 22 combined with painting Bedulu village youth. In the case of art; sculpture and dance, Kecak Bedulu has been known since 1930 with the theme-Subali Sugriva, (Astawa, 2012). Bedulu Village area is quite spacious with a population of 723 households. Lifestyle of the people still show traditional villages, crossroads are part of the northeast corner of Castle Bedulu, which is a legacy of the King of Bedulu. Pakraman Bedulu limits: in the northern village of Pejeng, the east side of the River Canyon in the south confluence of the gulf and Petanu (Campuhan), the west side of the Petanu River. Bedulu is an ancient village that has been inhabited since prehistoric times, before the entry of Hindu-Buddhist influence, they live in groups (hamlets) with a simple lifestyle around 2000-2500 years ago with a burial system Sarcophagus. The influence of Hindu Buddha's first entry in the village Bedulu with meteri proof clay (Subak penyembulan Bedulu) and Shiva statue Mahaguru stored in Pura village Alit derived from 8-10 century AD.

Cultural sites, archaeological, tourist area of Goa Gajah, Relief Yeh Pulu and local arts and culture are unique and interesting to make potentially Bedulu village as tourism village. Public participation in the tourist village well as cooks, dancers, waiters, room cleaners and painters impact of social, cultural, economic and environmental sustainability of local villages.

\section{Results and Discussion}

Based on data collected from 52 respondents, consisting of people who participate in the activities of a tourist village, then in more detail described as follows.

The analysis technique used in analyzing this problem is simple regression to calculate the impact of public participation in the social, cultural, economic and environmental. Simple regression model is described as follows:

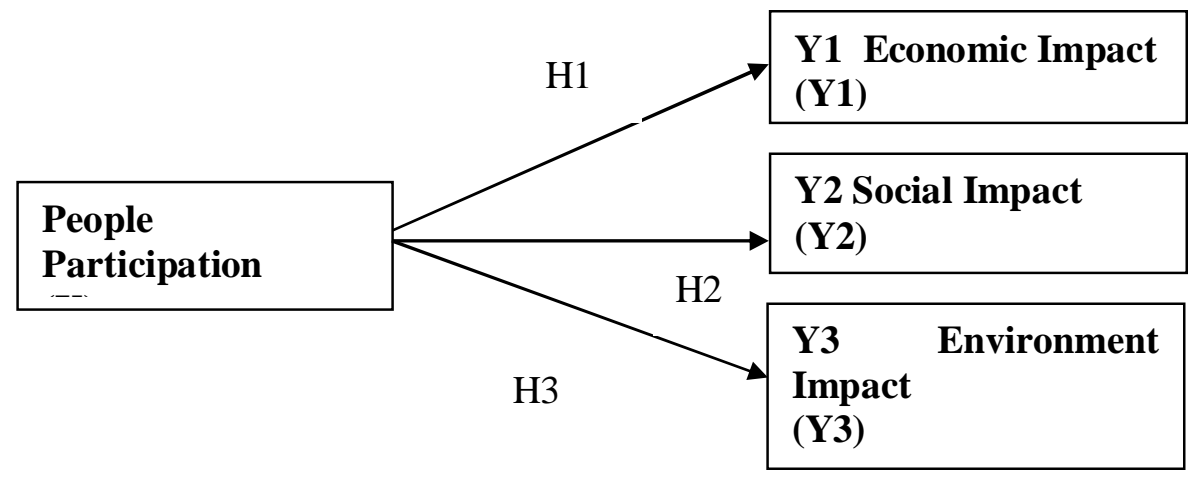




\section{Figure 1}

\section{Conceptual Framework}

Results of Data Processing With SPSS 18 as follows:

1. Impact of community participation in the economy

Table 1

Model Summary ${ }^{\mathrm{b}}$

\begin{tabular}{|c|c|r|r|r|}
\hline Model & R & R Square & $\begin{array}{c}\text { Adjusted R } \\
\text { Square }\end{array}$ & $\begin{array}{c}\text { Std. Error of } \\
\text { the Estimate }\end{array}$ \\
\hline 1 & $.321^{\mathrm{a}}$ & .103 & .085 & 29.87781 \\
\hline
\end{tabular}

a. Predictors: (Constant), Partisipasi

b. Dependent Variable: Ekonomi

Table 2

ANOVA $^{\text {a }}$

\begin{tabular}{|rc|r|r|r|r|r|}
\hline & \multicolumn{1}{|c|}{$\begin{array}{c}\text { Sum of } \\
\text { Model }\end{array}$} & Squares & df & Mean Square & F & Sig. \\
\hline 1 & Regression & 5128.288 & 1 & 5128.288 & 5.745 & $.020^{\mathrm{b}}$ \\
& Residual & 44634.176 & 50 & 892.684 & & \\
& Total & 49762.464 & 51 & & & \\
\hline
\end{tabular}

a. Dependent Variable: Ekonomi

b. Predictors: (Constant), Partisipasi

Table 3

Coefficients $^{\mathrm{a}}$

\begin{tabular}{|c|c|c|c|c|c|}
\hline \multirow[b]{2}{*}{ Model } & \multicolumn{2}{|c|}{$\begin{array}{l}\text { Unstandardized } \\
\text { Coefficients }\end{array}$} & \multirow{2}{*}{$\begin{array}{c}\begin{array}{c}\text { Standardized } \\
\text { Coefficients }\end{array} \\
\text { Beta }\end{array}$} & \multirow[b]{2}{*}{$\mathrm{t}$} & \multirow[b]{2}{*}{ Sig. } \\
\hline & B & Std. Error & & & \\
\hline (Constant) & 193.820 & 23.948 & & 8.094 & .000 \\
\hline Partisipasi & .283 & .118 & .321 & 2.397 & .020 \\
\hline
\end{tabular}

a. Dependent Variable: Ekonomi

Analysis

1) Figures $\mathrm{R}$ Square is 0.103 , meaning that $10.3 \%$ variable impact on the participation of the local economy. By $(100 \%-10.3 \%),=80.7 \%)$ have an impact on other variables.

2) Based on the ANOVA or F Test, calculated $F$ value is 5.745 to 0.020 significantly. Because the probability $(0,020)$ is smaller than $(0.05)$, then the regression can be used to predict the level of community participation.

3) The regression equation is $\mathrm{Y} 1=193.820+3,891 \mathrm{X}$. Constants 193.820 states that if there is no public participation, the economic impact amounted to 193820 tourist village. If there is an increase of public participation $(\mathrm{X}=1)$, the economic impact will increase by 3.891 . 
2. Impact of the Socio-Cultural Community Participation

Table 4

Model Summary ${ }^{b}$

\begin{tabular}{|c|c|r|r|r|}
\hline Model & R & R Square & $\begin{array}{c}\text { Adjusted R } \\
\text { Square }\end{array}$ & $\begin{array}{c}\text { Std. Error of } \\
\text { the Estimate }\end{array}$ \\
\hline 1 & $.038^{\mathrm{a}}$ & .001 & -.019 & 40.17935 \\
\hline
\end{tabular}

a. Predictors: (Constant), Partisipasi

b. Dependent Variable: Sosial

Table 5

ANOVA ${ }^{\mathrm{a}}$

\begin{tabular}{|rc|r|r|r|r|r|}
\hline & Sum of & & & & \\
& Model & Squares & df & Mean Square & F & Sig. \\
\hline 1 & Regression & 116.438 & 1 & 116.438 & .072 & $.789^{\mathrm{b}}$ \\
& Residual & 80718.997 & 50 & 1614.380 & & \\
& Total & 80835.435 & 51 & & & \\
\hline
\end{tabular}

a. Dependent Variable: Sosial

b. Predictors: (Constant), Partisipasi

Tabel 6

Coefficients $^{\text {a }}$

\begin{tabular}{|c|c|c|c|c|c|}
\hline \multirow[b]{2}{*}{ Model } & \multicolumn{2}{|c|}{$\begin{array}{c}\text { Unstandardized } \\
\text { Coefficients } \\
\end{array}$} & \multirow{2}{*}{\begin{tabular}{|c|c}
$\begin{array}{c}\text { Standardized } \\
\text { Coefficients }\end{array}$ \\
Beta \\
\end{tabular}} & \multirow[b]{2}{*}{$\mathrm{t}$} & \multirow[b]{2}{*}{ Sig. } \\
\hline & B & Std. Error & & & \\
\hline (Constant) & 241.615 & 32.204 & & 7.503 & .000 \\
\hline Partisipasi & .043 & .159 & .038 & .269 & .789 \\
\hline
\end{tabular}

a. Dependent Variable: Sosial

Analysis

1) Figures $\mathrm{R}$ Square is 0,001 , this means that $0.1 \%$ variable impact on people's social participation. By $(100 \%-0.13 \%),=90.9 \%)$ have an impact on other variables.

2) Based on ANOVA or F Test, calculated $F$ value is 0.72 with a 0.789 significant. Because the probability (0.789) is greater than $(0.05)$, then this regression can not be used to predict the level of community participation.

3) The regression equation is $\mathrm{Y} 1=241.615+0,43 \mathrm{X}$. Constants 241.615 states that if there is no public participation, the social impact of the tourist village of 241.615. If there is an increase of public participation $(X=1)$, the social impact increased by 0.43 . 
3 Impact on the Environment Participation

Table 7

Model Summary ${ }^{\mathrm{b}}$

\begin{tabular}{|c|c|r|r|r|}
\hline Model & R & R Square & $\begin{array}{c}\text { Adjusted R } \\
\text { Square }\end{array}$ & $\begin{array}{c}\text { Std. Error of } \\
\text { the Estimate }\end{array}$ \\
\hline 1 & $.092^{\mathrm{a}}$ & .008 & -.011 & 29.59120 \\
\hline
\end{tabular}

a. Predictors: (Constant), Partisipasi

b. Dependent Variable: Lingkungan

\section{Table 8}

ANOVA ${ }^{\text {a }}$

\begin{tabular}{|rc|r|r|r|r|r|}
\hline & Sum of & & & \\
& Model & Squares & Df & Mean Square & F & Sig. \\
\hline 1 & Regression & 373.679 & 1 & 373.679 & .427 & $.517^{\mathrm{b}}$ \\
& Residual & 43781.956 & 50 & 875.639 & & \\
& Total & 44155.634 & 51 & & & \\
\hline
\end{tabular}

a. Dependent Variable: Lingkungan

b. Predictors: (Constant), Partisipasi

Table 9

Coefficients $^{\text {a }}$

\begin{tabular}{|c|c|c|c|c|c|}
\hline \multirow[b]{2}{*}{ Model } & \multicolumn{2}{|c|}{$\begin{array}{c}\text { Unstandardized } \\
\text { Coefficients } \\
\end{array}$} & \multirow{2}{*}{\begin{tabular}{|c|}
$\begin{array}{c}\text { Standardized } \\
\text { Coefficients }\end{array}$ \\
Beta \\
\end{tabular}} & \multirow[b]{2}{*}{$\mathrm{t}$} & \multirow[b]{2}{*}{ Sig. } \\
\hline & B & Std. Error & & & \\
\hline (Constant) & 215.423 & 23.718 & & 9.083 & .000 \\
\hline Partisipasi & -.076 & .117 & -.092 & -.653 & .517 \\
\hline
\end{tabular}

a. Dependent Variable: Lingkungan

Analysis

1) Figures $\mathrm{R}$ Square is 0,008 , this means that $0.8 \%$ variable impact on the participation of the community. By $(100 \%-0.8 \%),=90.8 \%)$ have an impact on other variables.

2) Based on the ANOVA or F Test, calculated $F$ value is 0.427 to 0.517 significantly. Because the probability $(0.517)$ is greater than $(0.05)$, then this regression can not be used to predict the level of community participation.

3) The regression equation is $\mathrm{Y} 1=215.423-0,76 \mathrm{X}$. Constants 512.423 states that if there is no public participation, the environmental impact on the tourist village of 241615 . If a decline in community participation for ( $\mathrm{x}=$ $1)$, the environmental impact will decrease by 0.76 .

Based on analysis of the three variables above, it appears that the public participation gives the greatest impact on the economic aspect, which reached $10.3 \%$. Other aspects look very small and insignificant. Based on the opinions and views of respondents who complete a questionnaire study, explained that the 
current direct benefits perceived by the public is increase on income. Nominal value clearly felt by the whole community involved in this tourist village. But the addition in terms of social and cultural values, preservation of the environment they feel has not been significant. When in fact the tourist village they are required to live a healthy, clean and communicate with tourists.

\section{Conclusions}

Based on the quantitative analysis states that participation in the tourist village perceived dominant impact on the economic sector. Socio-cultural and environmental sector have no impact if the application of this tourist village. To strengthen the economy of small communities, rural tourism program launched by the government must be encouraged. Tourism-based community economy provide huge opportunities for people in the lowest layer. Therefore, the participation of local communities must be improved.

\section{References}

Addo, Edward. (2011). Diversification of the Tourist Landscape on Ghana's Atlantic Coast: Forts, Castles and Beach Hotel/Resort Operations in the Tourism Industry. Journal of Tourism Consumption and Practice Volume 3 No.1 2011 ISSN 1757-031X 1

Amirudin. (2013). BPS Provinsi Bali No. 67/12/51/Th. VII, 2 Desember 2013 Kepala Bidang Statistik Distribusi BPS Provinsi Bali.

Ardika, I Gde. (2011). Wisata Desa, Konsep dan Pengembangannya, Disampaikan Dalam Seminar Implementasi DMO Labuanbajo, 21-23 September.

Astawa. Anak Agung dan John Ketut. (2012). Pengelola Desa Wisata Arkeologi Bedulu. Yayasan Dharmodayana. Puri Bedulu Gianyar.

Bali Dalam Angka. (2013). http : // bali. bps. go. id/ tabel_detail. php? ed= 611001\&od $=11 \& \mathrm{id}=11$.

Cecil A.K., Y.Y. Fu, S. Wang, S. Avgoustis (2010) Cultural tourism and quality of life: The current issue and full text archive of this journal is available at www.emeraldinsight.com/0007-070X.htm Nanyang Technological University, Singapore

Cuthill, Michael dan Fien, John. (2005). Research \& Evaluation Capacity building: Facilitating Citizen Participation in Local Governance, University of Queensland RMIT, (C) National Council of the Institute of Public Administration, Australia.

FAO. 2006. Participation in practice Lessons from the FAO People's Participation Programme,

Gede Agung, Anak Agung. (2010). Jumpa Pers Bupati Badung dengan Pengelola Desa Wisata, 28 Desember, Badung, Bali.

Gozana, Djenaldi. (2011). Bali Hotel Association (BHA) Coordinator, Denpasar, Bali.

Henderson, Joan C. (2007). Food tourism reviewed, The current issue and full text archive of this journal is available at www.emeraldinsight.com/0007070X.htm

http://mekongtourism.org/website/wp-content/uploads/downloads/2011/02/CBT- 
Handbook-Principles-and-Meanings-by-CBT-I-Thailand.pdf

http://www.air.itb.ac.id/wdp/archive/catagory/tourism-course, $\quad$ Model

Perencanaan Pariwisata Nasional dan Dampak Sosial Ekonomi, diakses 12 Juni 2012.

http://www.sciencepub.net/rural wroeditor@gmail.com

Islam, Faridul and Carlsen, Jack. (2010). Rural Tourism And Poverty In Bangladesh: Unlocking Opportunities For The Poor, Curtin University of Technology, WA, Curtin Sustainable Tourism Centre.

Kathiresan, K. (2006). Peoples Participation, Centre of Advanced Study in Marine Biology Annamalai University

Leanne Fullerton, Kathleen McGettigan, Simon Stephens, (2010) "Integrating management and marketing strategies at heritage sites", International Journal of Culture, Tourism and Hospitality Research, Vol. 4 Iss: 2, pp.108 $-117$

Lynch, (2002 )dalam Melanie K. Smith and Mike Robinson, 2006, Cultural Tourism in a Changing World, Politic Participation and Representation. Results of a longitudinal study. European Journal of Tourism Research 3(1), pp. 54-66

McGettigan, F and Burns, K, (2004), Community Tourism Research in Kiltimagh, 2003/04. In Quality of Life-Competing Value Perspective in Leasure and Tourism. ATLAS Conference Leeuwarden, The Netherlands, 19-21 June.

Pomeroy, R.S. and Katon, B.M. (2000). Mangrove rehabilitation and coastal resource management project (MRCRMP) of Mabini-Candijay, Bohol, Philippines: Cogtong Bay. In: Proceedings of Asia-Pacific Cooperation on Research for conservation of mangroves, Okinawa, Japan, pp. 265-278.

Putra, I.N.D \& Pitana, I.G. (2010). Pariwisata Pro Rakyat Meretas Jalan Mengentaskan Kemiskinan Indonesia. Jakarta, Kementerian Kebudayaan dan Pariwisata

Rouse, John. 2006. FAO. People's Participation Programme, Small Farmers and Rural Organizations Officer, SDA Food and Agriculture Organization of the United Nations Via delle Terme di Caracalla, 00100 Rome, Itali.

Samah, Asnarulkhadi Abu \& Aref, Fariborz. (2009). People's Participation in Community Development: A Case Study in, a Planned Village Settlement in Malaysia. Marsland Press World Rural Observations 2009;1(2):45-54, Dept. of Development Science, Faculty of Human Ecology Putra University, Malaysia

Suarthana, I Ketut Putra dan Karta, Ni Luh Putu Agustini. (2013). Model Partisipasi Masyarakat Dan Dampak Sosial Ekonomi Desa Wisata Purbakala Bedulu, Gianyar Bali p 20. Proceeding Doctoral Colloquium and Conference "Ethically Sustainable Business Practice and Green Economy" Program Magister Sains dan Doktor FEB UGM.

Sulistyowati, Ayu. (2011). Corporate Sosial Responsibility Bank Indonesia, Kompas.com (www.Indonesia.go.id, 2012).

Sugiyono. (2009). Metode Penelitian Bisnis (Pendekatan Kuantitatif, Kualitatif dan R\&D). Alfabeta. ISBN 978-979-8433-24-5.

Van Breugel, Liedewij. (2013). Community-based tourism: Local participation and perceived impacts A comparative study between two communities in Thailand. Research Master Social and Cultural Science Supervised by 
Prof. Paul Hoebink, Faculty of Social Sciences Radboud University Nijmegen

Winarno. (2004). Media Indonesia Alright. Available from: http ./ /www .Micom @ Media Indonesia.com. 